Ambiente \& Água - An Interdisciplinary Journal of Applied Science
ISSN 1980-993X - doi:10.4136/1980-993X
www.ambi-agua.net
E-mail: ambi.agua@gmail.com

\title{
Flow distribution and trends in the Das Velhas River Basin
}

\author{
ARTICLES doi:10.4136/ambi-agua.2289
}

Received: 06 Jun. 2018; Accepted: 29 Mar. 2019

\author{
Larissa Silva Melo ${ }^{1 *(D)}$; João Carlos Ferreira Borges Júnior ${ }^{1(\mathbb{D})}$ \\ Ana Paula Coelho Madeira Silva ${ }^{2}[D$ \\ ${ }^{1}$ Universidade Federal de São João del-Rei (UFSJ), Sete Lagoas, MG, Brasil \\ Departamento de Ciências Agrárias (DCIAG). \\ E-mail: lalasmelo@yahoo.com.br,jcborges@ufsj.edu.br \\ ${ }^{2}$ Universidade Federal de São João del-Rei (UFSJ), Sete Lagoas, MG, Brasil \\ Departamento de Ciências Exatas e Biológicas (DECEB).E-mail: anapaula@ufsj.edu.br \\ *Corresponding author
}

\begin{abstract}
In the management of water resources, it is necessary to balance the demands of multiple uses of water and water availability, while enabling use in an environmentally sustainable way. Probability distributions of flow rates are essential tools for assessing water availability. The objectives of this work were to analyze the best probability distribution that conforms to the annual minimum daily average discharge for periods of seven consecutive days $\left(\mathrm{Q}_{7}\right)$ for 14 stream gauging stations in the Das Velhas River Basin and to identify possible trends in $\mathrm{Q}_{7}$ time series and in bi monthly and annual sets of daily discharges in three key stream gauging stations. The quality of fit was verified by the Anderson-Darling test (A-D). The selection of the models that presented the best fit was done according to the Bayesian Information Criterion (BIC). The Mann-Kendall test was used to verify trends in time series of discharge. In general, better measures of quality of fit were obtained for the probability distributions Gumbel and Rayleigh. Negative trends in discharge distributions were verified in the three stations. For the Várzea da Palma station, the closest to the river mouth, negative and significant trends were found for the $\mathrm{Q}_{7}$ data and daily average discharge for every bimester except the first.
\end{abstract}

Keywords: Mann-Kendall, model selection, water resources.

\section{Distribuições e tendências de vazões na bacia hidrográfica do Rio das Velhas}

\section{RESUMO}

Na gestão dos recursos hídricos se deve buscar a harmonização entre as demandas dos usos múltiplos da água e a disponibilidade hídrica, entendendo-se esta como o quantitativo a ser utilizado de forma ambientalmente sustentável. Distribuições de probabilidade de vazões são ferramentas essenciais para avaliar a disponibilidade hídrica. Os objetivos deste trabalho foram analisar qual a melhor distribuição de probabilidade que se ajusta aos dados mínimos anuais de vazão diária média em períodos consecutivos de sete dias $\left(\mathrm{Q}_{7}\right)$ de 14 estações fluviométricas da Bacia do Rio das Velhas e identificar possíveis tendências nas séries de $\mathrm{Q}_{7}$ e em conjuntos bimestrais e anuais de vazões diárias em três relevantes estações. $\mathrm{O}$ ajuste das distribuições foi verificado pelo teste de Anderson-Darling (A-D). A seleção dos modelos que apresentaram 
melhor ajuste foi feita segundo o Critério de Informação Bayesiano (BIC). Para analisar a tendência das vazões, foi utilizado o teste estatístico Mann-Kendall. As distribuições que em geral melhor se ajustaram aos dados e ocuparam a melhor posição no ranking foram Gumbel e Rayleigh. Constataram-se tendências negativas nas três estações. Para a estação de Várzea da Palma, a mais próxima da foz do rio, foram encontradas tendências negativas e significativas para os dados do $\mathrm{Q}_{7}$ e vazão média diária para todos os bimestres, exceto o primeiro.

Palavras-chave: Mann-Kendall, recursos hídricos, seleção de modelos.

\section{INTRODUCTION}

Concerns about sustainability of water resources arise frequently in discussions related to environmental and socioeconomic issues at global, regional and local levels. The exploitation of natural resources, without regard for sustainability, negatively impacts relationships between water availability and demand, limiting regional strategies of social and economic development covering multiple uses, among them public water supply and irrigation.

The growing importance given to rational water use has been motivating evolutions in systems of planning, administration and use of the water resources, in the search for an effective answer to social demands. To adequately manage water potential, it is fundamental to know the hydrological characterization of the basin, considering temporal and spatial variability. Knowledge of flow distribution, identifying the probability of maximum and minimum discharges events, is a fundamental aspect of this characterization.

In the management of water resources, it is necessary to continually balance water demands and availability, in an environmentally sustainable way. Mello et al. (2010) emphasizes the importance of the study of the probability distribution of hydrological variables, since from this knowledge it is possible to determine the appropriate reference values of discharge to estimate regional water availability.

Each state in Brazil has adopted specific criteria for the establishment of minimum reference flows that will inform studies on the granting of water-use rights. For situations in which water catchment will occur in rivers, the hydrological regime or discharge probability distributions should be considered in the analysis. For perennial rivers, the grant request is usually analyzed based on a percentage of the minimum discharge for a period of seven consecutive days and return period of ten years $\left(\mathrm{Q}_{7,10}\right)$ or minimum flows associated with the 95\% (Q95) or $90 \%\left(\mathrm{Q}_{90}\right)$ of probability.

From time series of discharges, it is possible to evaluate water availability and significant changes in the hydrological regime in the long run. Best-fit analysis to identify probability distribution can be applied to these series (Silva et al., 2015).

Santos (2010) argues that the randomness of hydrological processes make it difficult to predict. However, a quality of fit analysis of flow time series can be carried out for probabilistic or stochastic models. From this analysis, it is possible to infer (at a certain level of confidence) extreme flow values that are useful to the management of water resources.

On the other hand, trend analysis of discharges gives a basis to understand the impact of climate change and variations in the executed demands of multiple water uses, supporting the development and improvement of hydrological models applicable to water-resource management and scenario forecasting (Joseph et al., 2013).

The trend study of the components of the hydrological cycle is fundamental in the management of water resources. Through this analysis, government management councils can seek adjustments and courses of actions to ensure sustainability in the supply of water resources in harmony with the demand dynamics (Vilanova, 2014b; Kibria et al., 2016).

The identification of flow trends also contributes to the understanding of global climate 
variability and is essential for the development of hydrological models, hydrological forecasting and water-resource management. Climatic variability and disorderly use of the soil affect several components of the hydrological cycle, impacting the pattern of time series (Salvadori, 2013; Damázio and Costa, 2014; Tan and Gan, 2015; Agevap, 2016).

Statistical tests such as Pettitt and Mann-Kendall can be applied to trend analysis in the time series of meteorological and hydrological variables (Barua et al., 2013; Uliana et al., 2015). The Mann-Kendall test (MK) is recommended by the World Meteorological Organization (WMO) and widely applied (Blain, 2010; Caloiero et al., 2011; Lima et al., 2011; Suhaila et al., 2010; Tao et al., 2011). The Mann-Kendall test has been used in several studies of hydrological trends, mainly in flow-trend analysis. Its use is justified by the fact that it presents greater robustness regarding deviations of normality and non-stationarity of the data of the time series when compared to parametric tests. In addition, this test allows the detection and approximate location of the starting point of a certain trend (Costa et al., 2015; Salviano et al., 2016). Dale et al. (2015) applied the Mann-Kendall seasonal trend analysis method to test mean daily streamflow in gauging stations from 1948 through 2010 in the Cimarron-Skeleton Watershed (North Central Oklahoma), with a drainage area of $8275 \mathrm{~km}^{2}$. They verified the importance of adjusting irrigation to mitigate the impact of increasing climate variability on streamflow. Soares et al. (2018) performed the Mann-Kendal test to analyze climatic indicators of desertification in the Pajeú River Basin in the State of Pernambuco, Brazil, identifying trends for rainfall and dryness indexes.

In the State of Minas Gerais, Brazil, the Das Velhas River Basin and some others the criterion adopted was a maximum limit of $30 \%$ of $\mathrm{Q}_{7,10}$ to be granted for consumptive water use in the hydrographic basin portion bounded by each section considered under natural conditions. In Das Velhas River Basin, there are no studies related to probability distributions and flow trends. Segmentation of these analyses on a bimonthly basis makes it possible to identify critical periods in terms of management. The Das Velhas River is the largest tributary of the São Francisco River. In its basin is the region with the highest population density in the hydrographic unit of the São Francisco River, having significant economic importance for the State of Minas Gerais. The largest water catchment in the entire basin occurs at the upper reaches of the Das Velhas River channel, responsible for supplying about $74 \%$ of the urban demand in the Belo Horizonte and Metropolitan Region. In Strategic Territorial Units (STUs) of the high Das Velhas River region, the sectors that most draw water are industry and mining, except for the STU Nascentes, which has significant demand for irrigation. Irrigation is also the main sector responsible for the withdrawal of water in the STUs of the regions Middle Low and Lower of the Das Velhas River Basin.

The present work contributes to the updating of base studies for the management of water resources in the Das Velhas River Basin, from the perspective of expansion of irrigated agriculture, especially, among multiple uses. This study therefore analyzed the quality of fit of probability distribution models to data of annual minimum of average daily discharge for a period of seven consecutive days $\left(\mathrm{Q}_{7}\right)$ for 14 stream-gauging stations in Das Velhas River Basin and identified possible trends in $\mathrm{Q}_{7}$ time series and in bi monthly and annual sets of daily discharges in the stream gauging stations at Ponte Raul Soares, Santo Hipólito and Várzea da Palma.

\section{MATERIAL AND METHODS}

\subsection{Study Area}

The study area was the Das Velhas River Basin, located between the latitudes $17^{\circ} 15^{\prime} \mathrm{S}$ and $20^{\circ} 25^{\prime} \mathrm{S}$ and longitudes $43^{\circ} 25^{\prime} \mathrm{W}$ and $44^{\circ} 50^{\prime} \mathrm{W}$, in the central region of the state of Minas Gerais, comprising an area of $27,850 \mathrm{~km}^{2}$, which corresponds to $5 \%$ of the state area. The basin has a significant drainage density that feeds the main water course, which is $806.84 \mathrm{~km}$ long. 
Considering data of the current master plan of the basin (Comitê da Bacia Hidrográfica do Rio das Velhas, 2015), the $\mathrm{Q}_{7,10}$ is $48.31 \mathrm{~m}^{3} \mathrm{~s}^{-1}$. The lower Das Velhas River stretch is the one with the highest water availability in relation to $\mathrm{Q}_{7,10}\left(31.54 \mathrm{~m}^{3} \mathrm{~s}^{-1}\right)$, followed by stretches mediumhigh $\left(25.94 \mathrm{~m}^{3} \mathrm{~s}^{-1}\right)$, middle-lower $\left(17.46 \mathrm{~m}^{3} \mathrm{~s}^{-1}\right)$ and high $\left(13.58 \mathrm{~m}^{3} \mathrm{~s}^{-1}\right)$. The main segments responsible for effective water consumption are urban supply and irrigation, which account for $50.48 \%$ and $36.44 \%$ of total consumption, respectively. The water consumption by irrigation prevails especially in the STUs of the regions Middle and Low of the Das Velhas River Basin. In the STUs of the High region of the Das Velhas River Basin, the consumption of water for mining, industry and urban supply prevails.

According to information on the portal HidroWeb (2013), in this area there are 54 stream gauging stations, 14 are the responsibility of ANA, 30 of IGAM, 5 of CEMIG, 4 of CODEVASF and 1 of DNOS. The focus of the work was on the 14 stations that are the responsibility of the National Water Agency (ANA), whose dispositions in the basin are presented in Figure 1, for which discharge data are available.

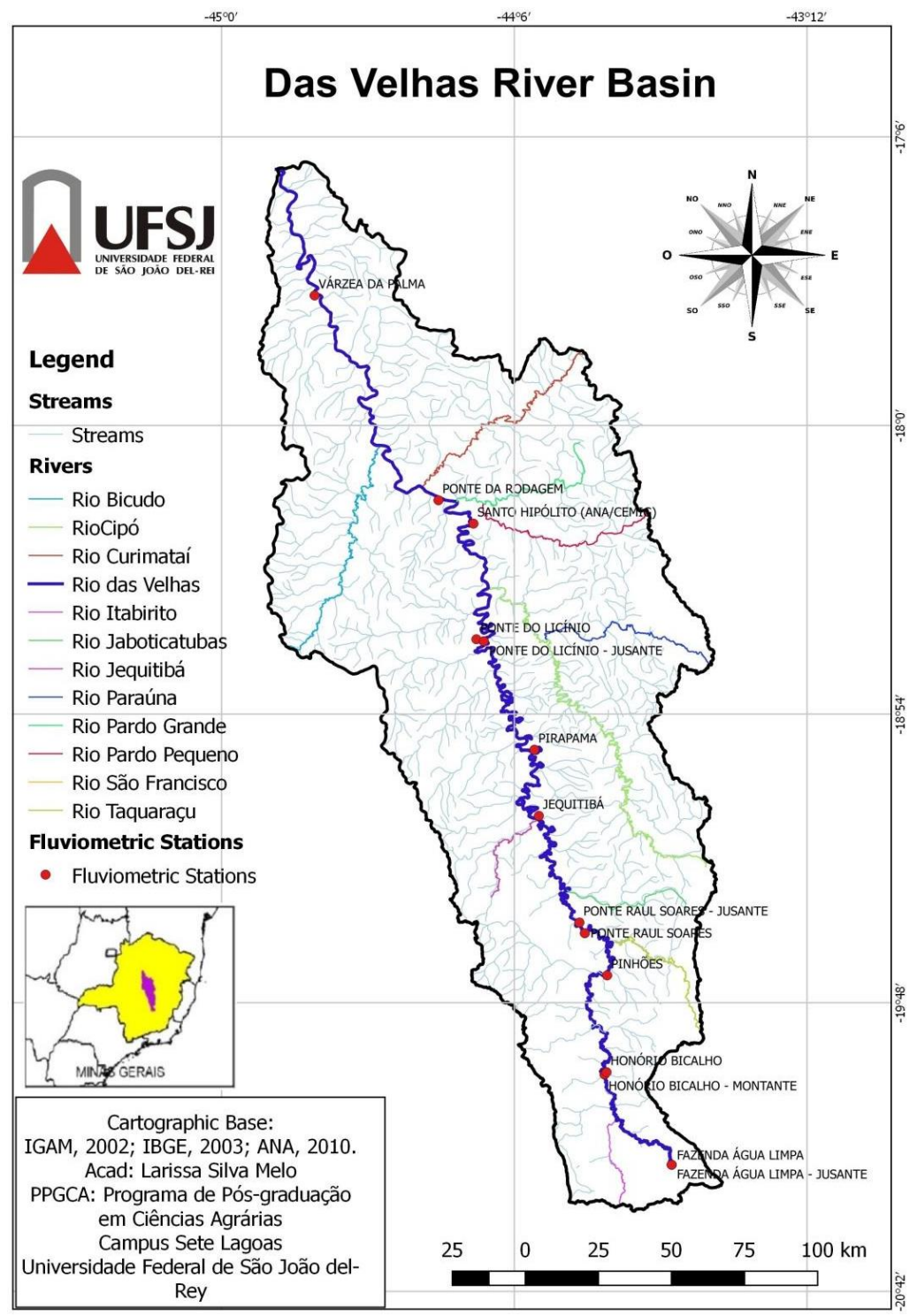

Figure 1. Location of the 14 stream gauging stations considered in the study. 
The time series of discharge data was obtained from the HidroWeb system of the ANA. The stream gauging stations considered in this study are shown in Table 1. Data of the stream gauging stations and characteristics of the data set are presented in Table 1 and Table 2, respectively.

Table 1. Stream gauging stations in Das Velhas River Basin considered working, for which the National Water Agency (ANA) is responsible.

\begin{tabular}{|c|c|c|c|c|c|c|}
\hline Name & Code & County & Latitude $\left({ }^{\circ}\right)$ & Longitude $\left(^{\circ}\right)$ & $\begin{array}{l}\text { Altitude } \\
(\mathrm{m})\end{array}$ & $\begin{array}{l}\text { Drainage area } \\
\qquad\left(\mathrm{km}^{2}\right)\end{array}$ \\
\hline $\begin{array}{l}\text { Fazenda } \\
\text { Água } \\
\text { Limpa }^{(1)}\end{array}$ & 41150000 & Ouro Preto & -20.30528 & -43.61639 & 965 & 175 \\
\hline $\begin{array}{l}\text { Fazenda } \\
\text { Água } \\
\text { Limpa } \\
\text { Jusante }\end{array}$ & 41151000 & Ouro Preto & -20.30528 & -43.61639 & 965 & 175 \\
\hline $\begin{array}{l}\text { Honório } \\
\text { Bicalho } \\
\text { ANA }^{(1)}\end{array}$ & 41200000 & Nova Lima & -20.01667 & -43.81667 & 721 & 1550 \\
\hline $\begin{array}{l}\text { Honório } \\
\text { Bicalho } \\
\text { Montante }^{(2)}\end{array}$ & 41199998 & Nova Lima & -20.02389 & -43.82278 & 721 & 1550 \\
\hline Jequitibá ${ }^{(2)}$ & 41410000 & Jequitibá & -19.22222 & -44.02472 & 650 & 7080 \\
\hline Pinhões (2) & 41260000 & Santa Luzia & -19.70500 & -43.81472 & $671^{(3)}$ & 3730 \\
\hline Pirapama ${ }^{(2)}$ & 41600000 & Cordisburgo & -19.01111 & -44.03833 & 616 & 8050 \\
\hline $\begin{array}{l}\text { Ponte da } \\
\text { Rodagem }^{(1)}\end{array}$ & 41840000 & Santo Hipólito & -18.23333 & -44.33333 & 464 & 19000 \\
\hline $\begin{array}{l}\text { Ponte do } \\
\text { Licínio }^{(1)}\end{array}$ & 41650000 & $\begin{array}{l}\text { Presidente } \\
\text { Juscelino }\end{array}$ & -18.66667 & -44.21667 & 560 & 10700 \\
\hline $\begin{array}{l}\text { Ponte do } \\
\text { Licínio } \\
\text { Jusante }\end{array}$ & 41650002 & $\begin{array}{c}\text { Presidente } \\
\text { Juscelino }\end{array}$ & -18.67278 & -44.19389 & 560 & 10700 \\
\hline $\begin{array}{l}\text { Ponte Raul } \\
\text { Soares }{ }^{(2)}\end{array}$ & 41340000 & Lagoa Santa & -19.55972 & -43.91111 & 637 & 4860 \\
\hline $\begin{array}{l}\text { Ponte Raul } \\
\text { Soares } \\
\text { Jusante }^{(1)}\end{array}$ & 41340005 & Jaboticatubas & -19.55000 & -43.90000 & 637 & 4860 \\
\hline $\begin{array}{l}\text { Santo } \\
\text { Hipólito (2) }\end{array}$ & 41818000 & Santo Hipólito & -18.30611 & -44.22583 & 499 & 16600 \\
\hline $\begin{array}{l}\text { Várzea da } \\
\text { Palma }{ }^{(2)}\end{array}$ & 41990000 & $\begin{array}{c}\text { Várzea Da } \\
\text { Palma }\end{array}$ & -17.59472 & -44.71389 & 464 & 26500 \\
\hline
\end{tabular}

Source: Adapted of HidroWeb (2013). ${ }^{(1)}$ operator ANA; ${ }^{(2)}$ operator CPRM, ${ }^{(3)}$.

Source: Google Earth. 
Table 2. Characteristics of discharge data sets of the stations in the Das Velhas River Basin.

\begin{tabular}{|c|c|c|c|c|c|c|}
\hline Stations & Start & End & $\begin{array}{l}\text { Total } \\
\text { Data }\end{array}$ & $\begin{array}{l}\text { Total } \\
\text { Failures }\end{array}$ & $\begin{array}{c}\% \\
\text { Failures }\end{array}$ & $\begin{array}{c}\text { Failures in 7-day } \\
\text { datasets }\end{array}$ \\
\hline Fazenda Água Limpa & 01/06/1956 & $31 / 05 / 1994$ & 13745 & 134 & 0.974 & 380 \\
\hline $\begin{array}{l}\text { Fazenda Água Limpa } \\
\text { Jusante }\end{array}$ & 01/05/1994 & $31 / 01 / 2015$ & 7410 & 171 & 2.307 & 323 \\
\hline $\begin{array}{l}\text { Honório Bicalho } \\
\text { ANA }\end{array}$ & $01 / 09 / 1963$ & $31 / 12 / 1970$ & 2669 & 10 & 0.374 & 58 \\
\hline $\begin{array}{l}\text { Honório Bicalho } \\
\text { Montante }\end{array}$ & 01/04/1971 & $31 / 01 / 2015$ & 15646 & 366 & 2.339 & 668 \\
\hline Jequitibá & $01 / 06 / 1965$ & $31 / 12 / 2014$ & 17998 & 113 & 0.627 & 449 \\
\hline Pinhões & 01/09/1975 & $31 / 12 / 2014$ & 13801 & 566 & 4.101 & 860 \\
\hline Pirapama & 01/07/1956 & $31 / 01 / 2015$ & 19323 & 2076 & 10.743 & 2521 \\
\hline Ponte da Rodagem & $01 / 07 / 1965$ & $31 / 12 / 1970$ & 1912 & 98 & 5.125 & 134 \\
\hline Ponte do Licínio & 01/08/1941 & $31 / 12 / 1976$ & 12385 & 552 & 4.457 & 901 \\
\hline $\begin{array}{l}\text { Ponte do Licínio } \\
\text { Jusante }\end{array}$ & 01/05/1976 & $31 / 01 / 2015$ & 13862 & 293 & 2.113 & 592 \\
\hline Ponte Raul Soares (*) & $01 / 02 / 1938$ & $30 / 04 / 2013$ & 24045 & 3437 & 14.294 & 3996 \\
\hline $\begin{array}{l}\text { Ponte Raul Soares } \\
\text { Jusante }\end{array}$ & 01/11/1976 & $31 / 01 / 1983$ & 2172 & 111 & 5.110 & 165 \\
\hline Santo Hipólito (*) & 01/06/1938 & $31 / 01 / 2015$ & 26278 & 1726 & 6.568 & 2437 \\
\hline Várzea da Palma $(*)$ & 01/06/1938 & $31 / 01 / 2015$ & 27754 & 250 & 0.900 & 887 \\
\hline
\end{tabular}

(*) Stations selected for trend study.

\subsection{Calculation of the minimum flow $\mathbf{Q}_{7}$}

The moving average of seven consecutive days of mean daily discharge was calculated. For each station, the annual lowest values of the moving averages for seven consecutive days $\left(\mathrm{Q}_{7}\right)$ were classified in ascending order forming a series for which the statistical analyses were carried out.

For non-complete consecutive seven-day sets of discharge values, it would not be possible to calculate the moving average without filling-in fail procedures. It was chosen in this work to not fill-in failures, discarding incomplete data sets, in order to not insert new sources of uncertainties in data series. The number of failures in seven-day datasets was counted for each station (Table 2).

\subsection{Goodness of fit analysis and model selection}

The probability distribution models were selected from bibliographic review (Almeida $e t$ al., 2014; Silvino et al., 2007; Silva et al., 2015; Smakhtin, 2001; Lopes et al., 2016; Rossi and Thebaldi, 2017; Pereira and Caldeira, 2018) and preliminary tests. Thus, the theoretical probability distributions used for the $\mathrm{Q}_{7}$ data were: Erlang, Gumbel (Extreme Value), Gamma, Inverse Gaussian, Weibull, Normal Log, Pearson 5, Log Logistics, Rayleigh, Triangular. Models parameters were estimated by the Maximum Likelihood Method (Mood et al., 1974). 
Anderson-Darling test (Razali and Wah, 2011) at 5\% significance level was applied to assess the quality of fit between empirical and theoretical distributions, i.e., for model selection. P-values and critical values were obtained by using the technique of parametric bootstrapping. The possibility of applying the technique of parametric bootstrapping due to the computational procedures programmed in the software used was considered as an additional criterion for selecting models. After that, the Bayesian Information Criterion (BIC) (Emiliano et al., 2009; Detzel et al., 2014; Pinto et al., 2015) was applied to rank the selected models. The software @ Risk version 7.0.1 (Palisade, 2016) was employed to run the tests.

\subsection{Trend analysis}

The mean daily discharge (volumetric flow rate) time series were analyzed in three stream gauging stations: Ponte Raul Soares, Várzea da Palma and Santo Hipólito. The data were grouped in the following categories: discharge $\mathrm{Q}_{7}$ (minimum average daily discharge in a period of seven consecutive days, for each year); general (daily discharge over the study period); daily discharges grouped in bimesters, that is: $1^{\text {st }}$ bimester (January and February); $2^{\text {nd }}$ bimester (March and April); $3^{\text {rd }}$ bimester (May and June); $4^{\text {th }}$ bimester (July and August); $5^{\text {th }}$ bimester (September and October); and $6^{\text {th }}$ bimester (November and December).

The Mann-Kendall test was applied at a 5\% significance level. The analyses were performed using the software R version 3.3.1 (R Core Team, 2016), with the "Kendall" package (McLeod, 2011).

Rainfall trend was also investigated by using the Mann-Kendall test for the three INMET (Brazilian National Institute of Meteorology) conventional meteorological stations in the Das Velhas River Basin. The data were obtained in the database BDMEP (Meteorological Database for Teaching and Research). The time series cover periods from 1961 to 2018 for the stations of Belo Horizonte $\left(19.93^{\circ} \mathrm{S}, 43.93^{\circ} \mathrm{W}\right)$ and Curvelo $\left(18.75^{\circ} \mathrm{S}, 44.45^{\circ} \mathrm{W}\right)$, and to 2016 for the station of Sete Lagoas $\left(19.46^{\circ} \mathrm{S}, 44.25^{\circ} \mathrm{W}\right)$.

\section{RESULTS AND DISCUSSION}

\subsection{Model fit and selection}

Probability distributions that were fit to the data of annual minimum discharge for a period of seven days $\left(\mathrm{Q}_{7}\right)$ according to the Anderson-Darling test are presented in Table 3.

The probability distributions of Gumbel and Rayleigh were highlighted, since they fit to 8 and 5 stations of 14, respectively, according to the Anderson-Darling test and the possibility to apply the technique of parametric bootstrapping by the @ Risk software. Quality of fit was observed for the distributions of Inverse Gaussian, Log Logistic, Log Normal, Pearson 5 and Weibull for two stations. Adjustment to $\mathrm{Q}_{7}$ data was not verified for the Erlang, Gamma and Triangular distributions. No distribution was suitable to describe the data for the stations Água Limpa Farm, Água Limpa Fazenda, Honório Bicalho Montante, Pinhões and Ponte Raul Soares (p-value <0.05).

After checking the quality of fit of the models to the observed data, the ranking of these distributions was done through the BIC selection criterion, as presented in Table 4. The Gumbel distribution was highlighted, for which the best performance was verified for 4 of the studied stations, followed by the Rayleigh distribution. 
Table 3. Probability distributions that fit to $\mathrm{Q}_{7}$ data according to the Anderson-Darling test $(\alpha=5 \%)$.

\begin{tabular}{|c|c|c|c|c|c|c|c|c|c|c|}
\hline Stations & Erlang & Gama & Gumbel & $\begin{array}{l}\text { Inversa } \\
\text { Gaussiana }\end{array}$ & Log Logística & Log Normal & Pearson 5 & Rayleigh & Triangular & Weibull \\
\hline \multicolumn{11}{|l|}{ Fazenda Água Limpa } \\
\hline \multicolumn{11}{|l|}{$\begin{array}{l}\text { Fazenda Água Limpa } \\
\text { Jusante }\end{array}$} \\
\hline \multicolumn{11}{|l|}{ Honório Bicalho Montante } \\
\hline Honório Bicalho ANA & & & $\mathrm{X}$ & & & & & $\mathrm{X}$ & & \\
\hline Jequitibá & & & $\mathrm{X}$ & & & & & $\mathrm{X}$ & & \\
\hline \multicolumn{11}{|l|}{ Pinhões } \\
\hline Pirapama & & & $\mathrm{X}$ & & & & & $\mathrm{X}$ & & \\
\hline Ponte da Rodagem & & & $\mathrm{X}$ & & & & & $\mathrm{X}$ & & \\
\hline Ponte do Licínio & & & $\mathrm{X}$ & $\mathrm{X}$ & $\mathrm{X}$ & $\mathrm{X}$ & $\mathrm{X}$ & & & \\
\hline Ponte do Licínio Jusante & & & $\mathrm{X}$ & & & & & & & \\
\hline Ponte Raul Soares & & & $\mathrm{X}$ & & & & & & & $\mathrm{X}$ \\
\hline \multicolumn{11}{|l|}{ Ponte Raul Soares Jusante } \\
\hline Santo Hipólito & & & $\mathrm{X}$ & & & & & $\mathrm{X}$ & & $\mathrm{X}$ \\
\hline Várzea da Palma & & & & $\mathrm{X}$ & $\mathrm{X}$ & $\mathrm{X}$ & $\mathrm{X}$ & & & \\
\hline
\end{tabular}


Table 4. Ranking of probability distributions applied to the data of $\mathrm{Q}_{7}$ (annual minimum discharge with duration of seven days) according to the criterion of Bayesian classification (BIC).

\begin{tabular}{lllcl}
\hline Stations & Erlang Gama Gumbel & $\begin{array}{c}\text { Inversa } \\
\text { Gaussiana }\end{array}$ & Log Logística Log Normal Pearson 5 Rayleigh Triangular Weibull \\
\hline
\end{tabular}

Fazenda Água Limpa

Fazenda Água Limpa

Jusante

Honório Bicalho

Montante

\section{Honório Bicalho ANA}

Jequitibá

Pinhões

\section{Pirapama}

Ponte da Rodagem

Ponte do Licínio

Ponte do Licínio

Jusante

Ponte Raul Soares

Ponte Raul Soares

Jusante

Santo Hipólito

$\# 1$
\#2

\#5

\#1

\#1
\#2

\#1

$\# 1$

Várzea da Palma

\#3

\#4

\#2

\#1 
In a similar study, Silvino et al. (2007) used the Normal, Log-Normal, Exponential Range and Weibull probability distributions to estimate the minimum discharges of the Paraguay River. The distributions for which the data of the time series were best fitted were Weibull and Normal. Almeida et al. (2014) verified the quality of fit of the distributions Normal, Log Normal to 2 parameters, Weibull, Gumbel and Log Gumbel to data of time series of $\mathbf{Q}_{7}$ in the Miranda River Watershed. Among the studied distributions, Log Gumbel was the one that provided the best fit to the time series, proving to be the most reliable in the determination of minimum flows in the reference sub-basin. On the other hand, the Normal Log distribution was the worst distribution regarding the adjustment to the series data.

In a study on minimum flows, Victorino et al. (2014) used the Gumbel distributions for minimums, Fréchet, Log 2p, Log 3p, Gamma 2p, Gamma 3p and Weibull. The Log 2P, Log 3P and Gama $2 \mathrm{P}$ distributions were considered statistically adequate for the series of minimum annual discharges of the Grande River in the region of Barreiras (Bahia, Brazil), and Log 2P presented a more accurate adjustment than the others.

Silva et al. (2006) applied the Log Normal 3P, Weibull and Gumbel probability distributions to time series of annual minimum daily and $\mathrm{Q}_{7}$ discharges from the region of the high Grande River. The best fit was observed for the distribution Log Normal 3P.

Descriptive statistics measures for the empirical distributions of $\mathrm{Q}_{7}$ of the stream gauging stations are presented in Table 5. The minimum discharge values ranged from $0.25 \mathrm{~m}^{3} \mathrm{~s}^{-1}$ (Fazenda Água Limpa) to $44.94 \mathrm{~m}^{3} \mathrm{~s}^{-1}$ (Ponte da Rodagem). Maximum values of $\mathrm{Q}_{7}$ varied from $1.66 \mathrm{~m}^{3} \mathrm{~s}^{-1}$ for the Fazenda Água Limpa station to $180.03 \mathrm{~m}^{3} \mathrm{~s}^{-1}$ for the Ponte do Licínio station. The lowest $\mathrm{Q}_{7}$ was verified for the Ponte Raul Soares Jusante station $\left(1.21 \mathrm{~m}^{3} \mathrm{~s}^{-1}\right)$ and the highest for the Várzea da Palma station $\left(69.64 \mathrm{~m}^{3} \mathrm{~s}^{-1}\right)$. The range of mode was from 0.8221 (Ponte Raul Soares Jusante) to $72.7039 \mathrm{~m}^{3} \mathrm{~s}^{-1}$ (Santo Hipólito). For the median, values from 0.99 (Ponte Raul Soares Jusante) to $60.06 \mathrm{~m}^{3} \mathrm{~s}^{-1}$ (Várzea da Palma) were verified. The lowest value of standard deviation was $0.22 \mathrm{~m}^{3} \mathrm{~s}^{-1}$ (Fazenda Água Limpa Jusante station) and the highest value was $25.89 \mathrm{~m}^{3} \mathrm{~s}^{-1}$ (Ponte do Licínio station).

Table 5. Descriptive statistics for empirical distributions of $\mathrm{Q}_{7}\left(\mathrm{~m}^{3} \mathrm{~s}^{-1}\right)$ from stream gauging stations in the Das Velhas River Basin.

\begin{tabular}{lcccccccc}
\hline Station & Minimum & Maximum & Mean & Mode & Median & $\begin{array}{c}\text { Standard } \\
\text { Deviation }\end{array}$ & Asymmetry & Kurtosis \\
\hline $\begin{array}{l}\text { Fazenda Água } \\
\text { Limpa }\end{array}$ & 0.25 & 2.24 & 1.47 & 1.76 & 1.44 & 0.43 & -0.70 & 4.36 \\
$\begin{array}{l}\text { Fazenda Água } \\
\text { Limpa Jusante }\end{array}$ & 0.75 & 1.66 & 1.26 & 1.28 & 1.29 & 0.22 & -0.52 & 3.23 \\
$\begin{array}{l}\text { Honório Bicalho } \\
\text { Montante }\end{array}$ & 4.26 & 21.54 & 14.43 & 12.86 & 14.44 & 3.69 & -0.21 & 3.02 \\
Honório Bicalho & 10.05 & 17.27 & 13.18 & 11.31 & 12.54 & 2.60 & 0.82 & 2.44 \\
ANA & 17.14 & 58.69 & 33.05 & 31.08 & 31.24 & 8.47 & 0.83 & 3.88 \\
Jequitibá & 4.26 & 36.82 & 22.97 & 19.73 & 24.03 & 7.15 & -0.44 & 3.57 \\
Pinhões & 17.87 & 70.08 & 37.99 & 32.41 & 35.06 & 11.99 & 0.69 & 3.21 \\
Pirapama & 44.94 & 71.30 & 58.17 & 52.19 & 56.57 & 10.18 & 0.11 & 1.40 \\
Ponte da Rodagem & 21.56 & 180.03 & 45.81 & 31.34 & 40.24 & 25.89 & 4.17 & 24.37 \\
Ponte do Licínio & 17.53 & 76.16 & 44.15 & 49.67 & 43.14 & 13.26 & 0.57 & 3.72 \\
$\begin{array}{l}\text { Ponte do Licínio } \\
\text { Jusante }\end{array}$ & 10.74 & 51.74 & 29.08 & 23.41 & 27.31 & 8.51 & 0.55 & 2.90 \\
$\begin{array}{l}\text { Ponte Raul Soares } \\
\text { Ponte Raul Soares }\end{array}$ & 0.64 & 3.07 & 1.21 & 0.82 & 0.99 & 0.77 & 2.56 & 9.89 \\
Jusante & 24.25 & 105.73 & 60.57 & 72.70 & 57.65 & 17.53 & 0.67 & 3.24 \\
$\begin{array}{l}\text { Santo Hipólito } \\
\text { Várzea da Palma }\end{array}$ & 30.68 & 159.27 & 70.81 & 57.40 & 60.73 & 27.47 & 1.38 & 4.81 \\
\hline
\end{tabular}


Água Limpa Farm, Água Limpa Fazenda Jusante, Honório Bicalho Montante and Pinhões stations have a negative asymmetry. The range of values was from - 0.70 (Fazenda Água Limpa) to 4.17 (Ponte do Licínio). Values of kurtosis close to the normal distribution, that is, near 3 (mesokurtic), were found for most stations. However, high values of kurtosis, indicating a higher concentration of discharge values near the center of the distribution, were verified for the Ponte do Licínio and Ponte Raul Soares Jusante stations. Probability density functions for the empirical (input) and theoretical distributions for the stations of Santo Hipólito and Várzea da Palma are presented in Figure 2. Higher asymmetry and kurtosis indexes were observed in Várzea da Palma, characteristics that influenced the fitting of a different set of distributions in relation to that obtained for Santo Hipólito. The morphology of the upstream basin, relief, soil types, transmissivity and dimensions of aquifers, as well as rainfall patterns (intensity, duration and frequency) are some factors that can influence the characteristics of the distribution of flow values in a stream gauging such as asymmetry and kurtosis. These characteristics will determine the potential of theoretical probability models to fit to distributions of empirical data.

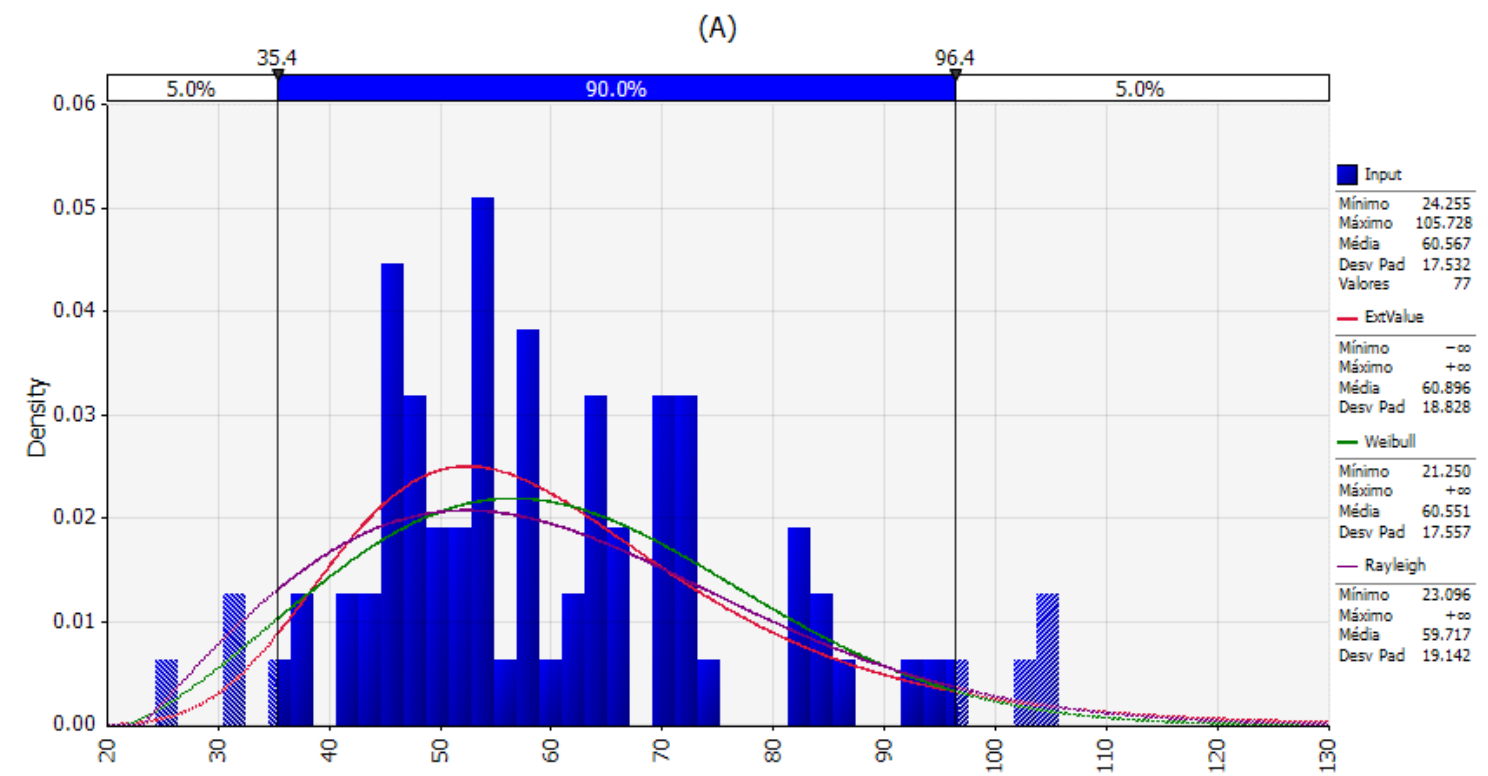

(B)

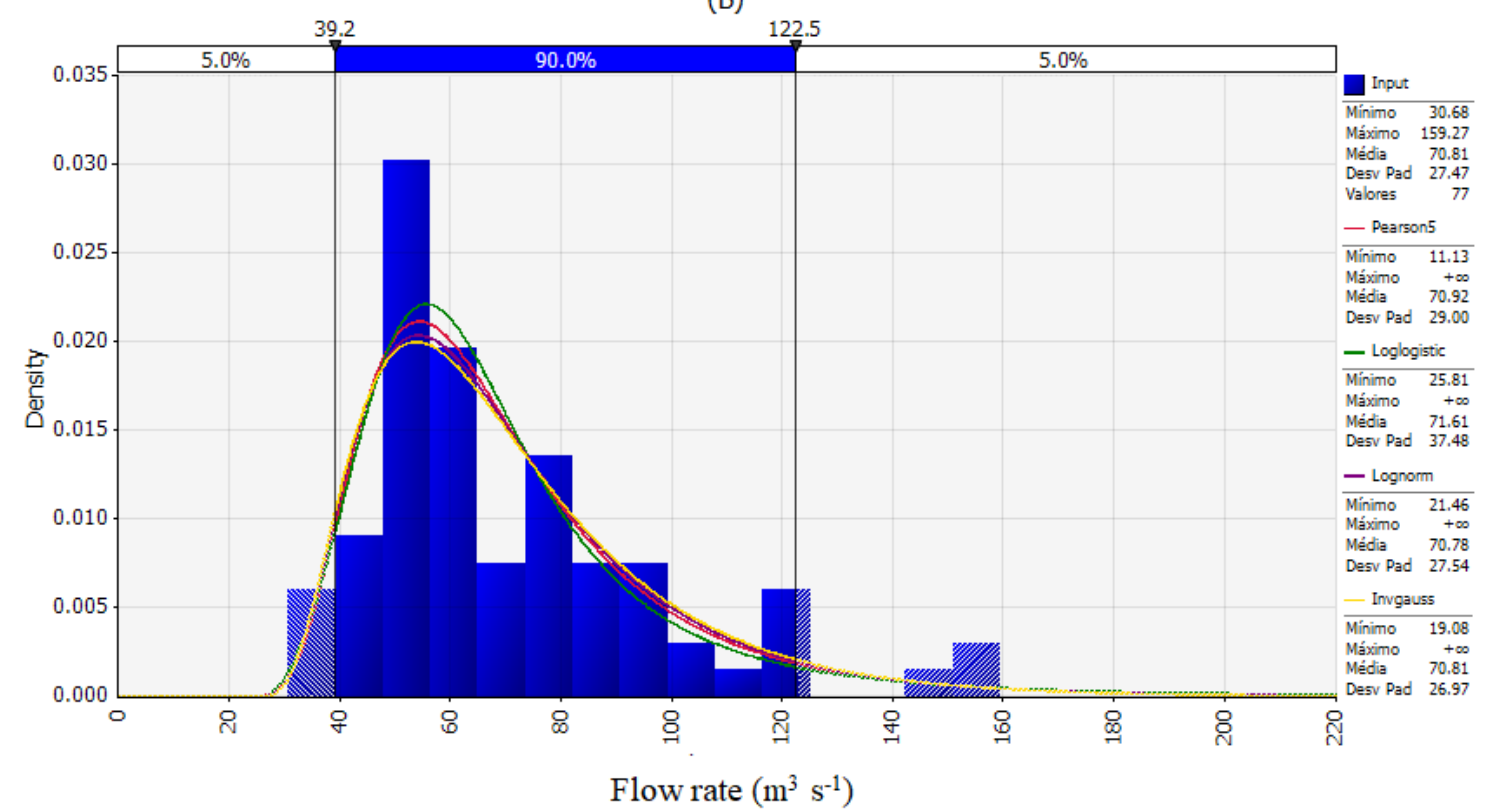

Figure 2. Empirical (input) and theoretical probability density functions for distributions of $\mathrm{Q}_{7}$ for the gauging stations of Santo Hipólito (A) and Várzea da Palma (B). 


\subsection{Trend Analysis}

The results of the trend analysis for the Ponte Raul Soares, Santo Hipólito and Várzea da Palma stations are presented in Tables 6 to 8. For the stream-gauging station Ponte Raul Soares (Table 6), negative trends were observed in all data sets, except for the $1^{\text {st }}$ and $6^{\text {th }}$ bimester (S positive). However, the negative trend was significant for the $\mathrm{Q}_{7}$ and $4^{\text {th }}$ bimester. Negative (decreasing) trends in all data sets (S negative) were detected for the Santo Hipólito station (Table 7). Based on the Mann-Kendall test, there were significant trends (p-value <0.05) for $\mathrm{Q}_{7}, 4^{\text {th }}$ and $5^{\text {th }}$ bimesters. For the Várzea da Palma station (Table 8), negative (decreasing) trends for all data sets ( $\mathrm{S}$ negative) were pointed out. Only for the $1^{\text {st }}$ bimester this trend was not significant ( $\mathrm{p}$-value> 0.05).

Table 6. Trend analysis of flow rate in the stream gauging station Ponte Raul Soares (S statistic, S variance (VAR (S)), denominator (D), Kendall correlation coefficient $(\tau)$ ).

\begin{tabular}{lccccc}
\hline & $\mathrm{S}$ & $\mathrm{VAR}(\mathrm{S})$ & $\mathrm{D}$ & $\tau$ & $\mathrm{p}$-value \\
\hline $\mathrm{Q}_{7}$ & $-499^{*}$ & 40588.33 & 2485 & -0.201 & 0.0134 \\
General & -83 & 40588.33 & 2485 & -0.033 & 0.6840 \\
$1^{\text {st }}$ bimester & 31 & 34147.67 & 2211 & 0.014 & 0.8710 \\
$2^{\text {nd }}$ bimester & -225 & 34147.67 & 2211 & -0.102 & 0.2254 \\
$3^{\text {rd }}$ bimester & -364 & 37275.33 & 2346 & -0.155 & 0.0601 \\
$4^{\text {th }}$ bimester & $-632^{*}$ & 49716.67 & 2850 & -0.222 & 0.0047 \\
$5^{\text {th }}$ bimester & -352 & 37275.33 & 2346 & -0.150 & 0.0691 \\
$6^{\text {th }}$ bimester & 99 & 34147.67 & 2211 & 0.045 & 0.5959 \\
\hline
\end{tabular}

* Significant by the Mann-Kendall test at the level of $5 \%$.

Table 7. Trend analysis of flow rate in the stream gauging station Santo Hipólito (S statistic, S variance (VAR (S)), denominator (D), Kendall correlation coefficient $(\tau)$ ).

\begin{tabular}{lccccc}
\hline & $\mathrm{S}$ & $\mathrm{VAR}(\mathrm{S})$ & $\mathrm{D}$ & $\tau$ & $\mathrm{p}$-value \\
\hline $\mathrm{Q}_{7}$ & $-576^{*}$ & 51692.67 & 2926 & -0.197 & 0.0114 \\
General & -324 & 51692.67 & 2926 & -0.111 & 0.1554 \\
$1^{\text {st }}$ bimester & -261 & 47791.67 & 2775 & -0.094 & 0.2343 \\
$2^{\text {nd }}$ bimester & -301 & 45917.00 & 2701 & -0.111 & 0.1615 \\
$3^{\text {rd }}$ bimester & -415 & 45917.00 & 2701 & -0.154 & 0.0534 \\
$4^{\text {th }}$ bimester & $-489^{*}$ & 45917.00 & 2701 & -0.181 & 0.0228 \\
$5^{\text {th }}$ bimester & $-555^{*}$ & 45917.00 & 2701 & -0.205 & 0.0097 \\
$6^{\text {th }}$ bimester & -145 & 47791.67 & 2775 & -0.052 & 0.5101 \\
\hline
\end{tabular}

* Significant by the Mann-Kendall test at the level of 5\%.

Table 8. Trend analysis of flow rate in the stream gauging station Várzea da Palma (S statistic, $\mathrm{S}$ variance (VAR (S)), denominator (D), Kendall correlation coefficient $(\tau))$.

\begin{tabular}{lccccc}
\hline & $\mathrm{S}$ & $\mathrm{VAR}(\mathrm{S})$ & $\mathrm{D}$ & $\mathrm{T}$ & $\mathrm{p}$-value \\
\hline $\mathrm{Q}_{7}$ & $-823^{*}$ & 51689.67 & 2924,5 & -0.281 & 0.0003 \\
General & $-583^{*}$ & 53720.33 & 3003 & -0.194 & 0.0120 \\
$1^{\text {st }}$ bimester & -424 & 51692.67 & 2926 & -0.145 & 0.0628 \\
$2^{\text {nd }}$ bimester & $-444^{*}$ & 49716.67 & 2850 & -0.156 & 0.0469 \\
$3^{\text {rd }}$ bimester & $-526^{*}$ & 51692.67 & 2926 & -0.180 & 0.0209 \\
$4^{\text {th }}$ bimester & $-612^{*}$ & 51692.67 & 2926 & -0.209 & 0.0072 \\
$5^{\text {th }}$ bimester & $-810^{*}$ & 51692.67 & 2926 & -0.277 & 0.0004 \\
$6^{\text {th }}$ bimester & $-466^{*}$ & 51692.67 & 2926 & -0.159 & 0.0408 \\
\hline
\end{tabular}

* Significant by the Mann-Kendall test at the level of $5 \%$. 
The lowest mean daily flows occurred in the fourth bimester in $65.0 \%, 61.6 \%$ and $61.3 \%$ of the years with all bimonthly sets in the stations of Raul Soares, Santo Hipólito and Várzea da Palma, respectively. The fifth bimester is second in relevance in the concentration of low flows. Significant negative trends for the $\mathrm{Q}_{7}$ and fourth bimester were indicated for the three stream-gauging stations. The time series of flow and nonparametric lowess (locally weighted scatterplot smoothing) regression (Lindsey and Sheather, 2010) for these two sets are shown in Figure 3. More pronounced decreases are observed in the first- and final thirds of the series.

(A)

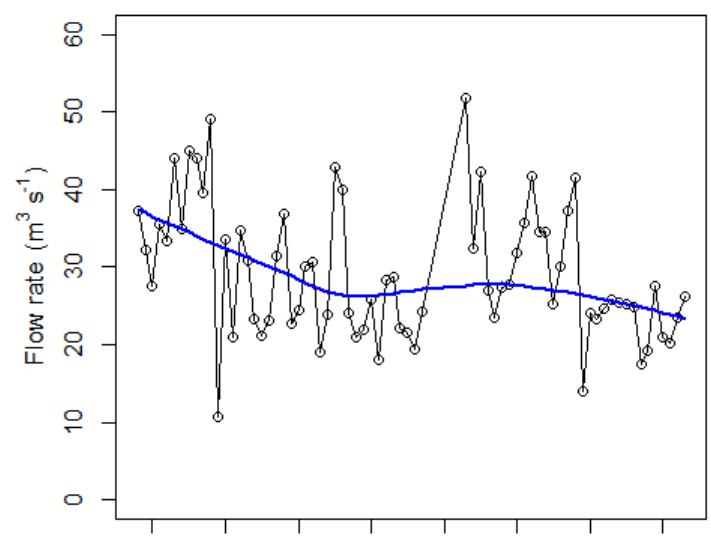

(C)

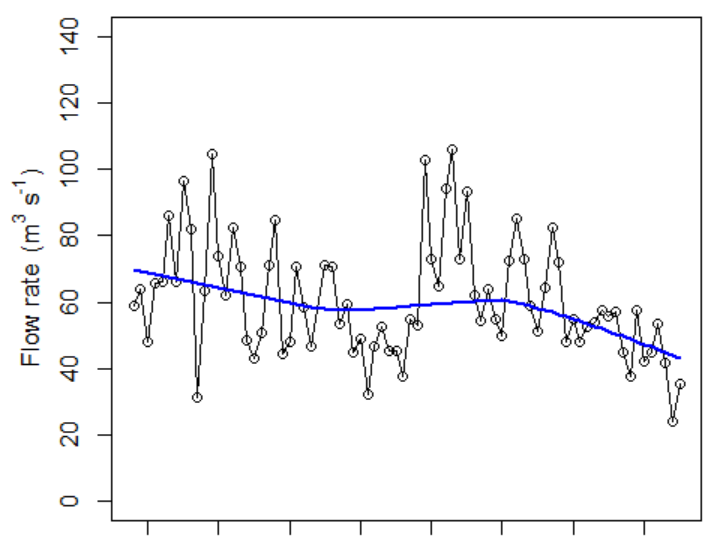

(E)

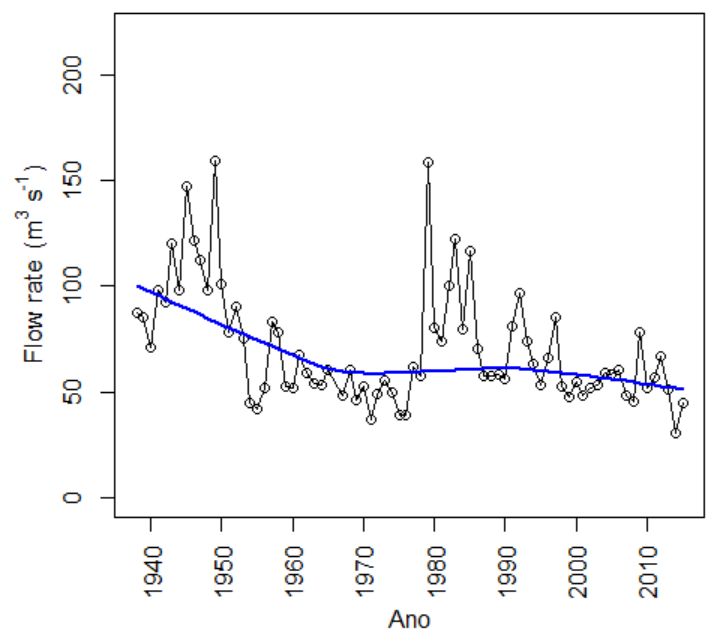

(B)

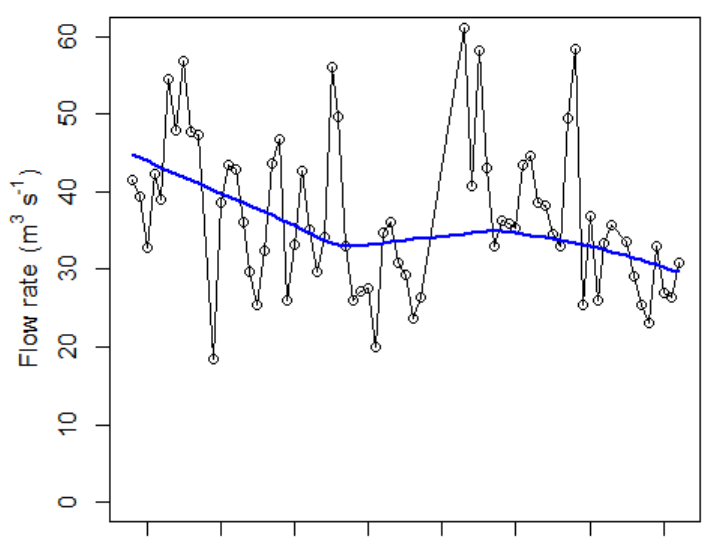

(D)

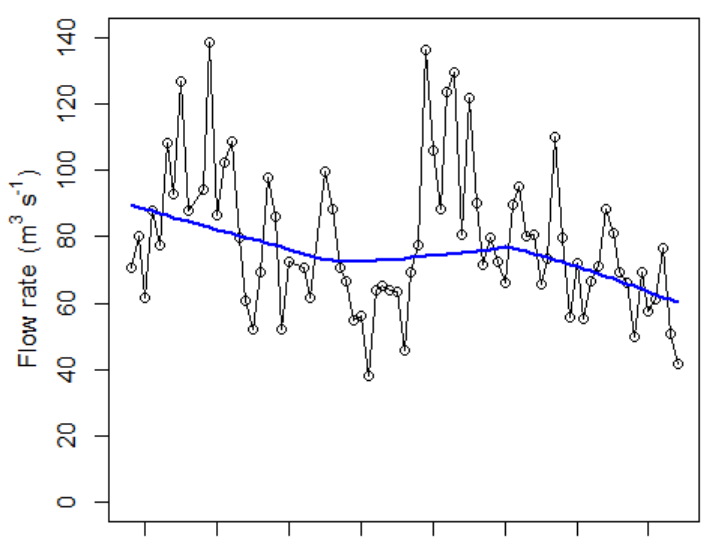

(F)

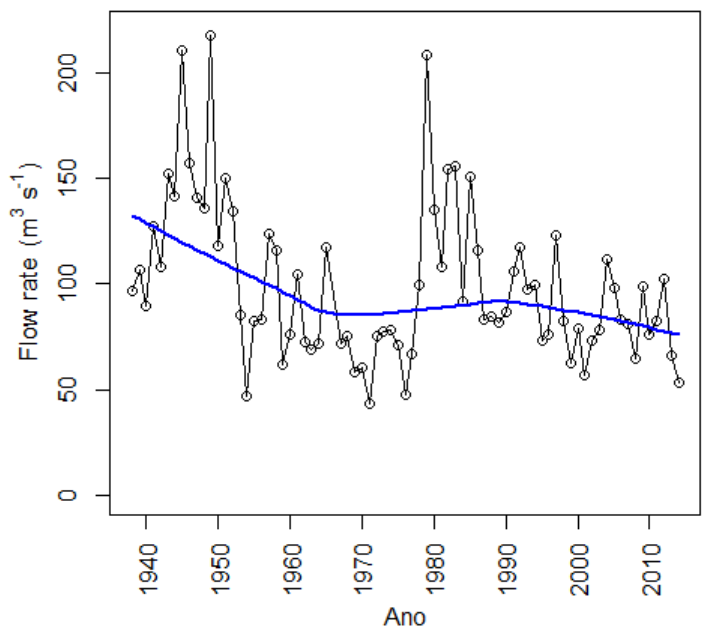

Figure 3. Time series of mean daily flow rate and nonparametric lowess regression for the stream-gauging stations of Ponte Raul Soares (A and B), Santo Hipólito (C and D), and Várzea da Palma (E and F); A, C, and E are series for $\mathrm{Q}_{7} ; \mathrm{B}, \mathrm{D}$, and $\mathrm{F}$ are series for $4^{\text {th }}$ bimester. 
Changes in hydrological series can occur due to different causes, such as variations in rainfall amounts and water withdrawals to meet multiple uses. The lowest values of $S$ are in the $4^{\text {th }}$ and $5^{\text {th }}$ bimesters, showing trends of decreasing flows. During these periods droughts occur, which contribute to a significant increase in irrigation demand. In $\mathrm{Q}_{7}$ data, a strong downward trend was also observed for the three stations, which is a worrisome factor regarding the management of water resources in the basin. According to the Water Resources Master Plan of the Das Velhas River Basin of 2015, for the strategic territorial units (STUs) Rio Bicudo, Ribeirão Picão, Ribeirão da Mata, Ribeirão Jequitibá, Rio Itabirito, Carste and high stretch of Das Velhas River, channel water withdrawal has already exceeded the criterion used (30\% of $\mathrm{Q}_{7,10)}$, preventing new grants (Comitê da Bacia Hidrográfica do Rio das Velhas, 2015).

There is a perspective of advancing irrigated agriculture in regions such as the lower Rio das Velhas. This advance imposes pressure on the demand for water resources with significant effects on water availability, which was partially detected at the Várzea da Palma station. The milder relief in this region favors the use of irrigation methods as a central pivot, among others, as can be observed in Figure 4. The presence of irrigated agriculture is also observed in the region of the county of Sete Lagoas (STU Ribeirão Jequitibá) in the region of the Middle Velhas - High Stretch, as shown in Figure 5. This figure also shows the great urban conglomerate of the capital of the state of Minas Gerais (Belo Horizonte) in the region of High Velhas.

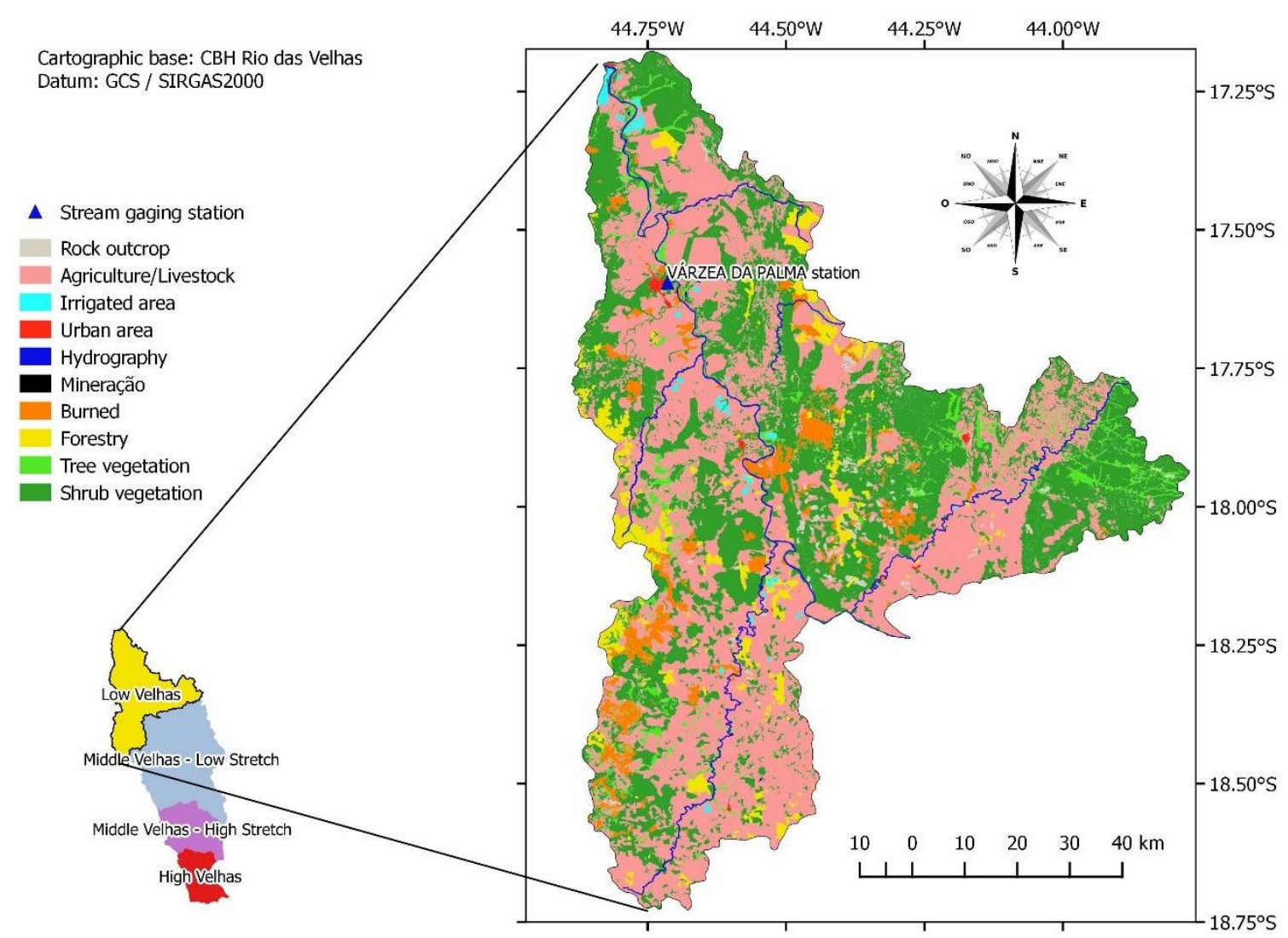

Figure 4. Land cover in the Low Velhas region, year 2013. 
Cartographic base: $\mathrm{CBH}$ Rio das Velhas Datum: GCS / SIRGAS2000
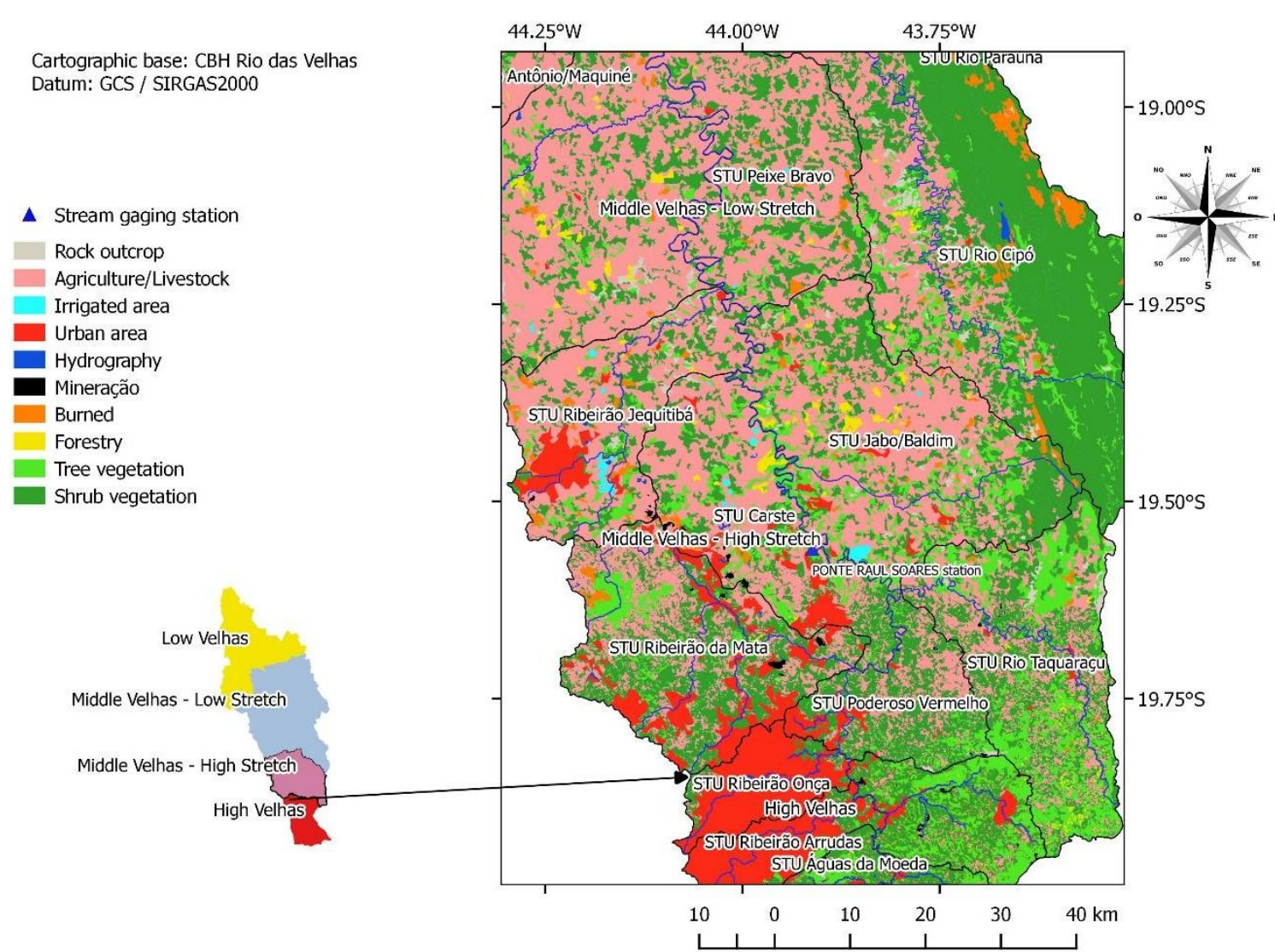

Figure 5. Land cover in the region Middle Velhas-High Stretch and parcial in the regions Middle Velhas-Low Stretch and High Velhas, year 2013.

Results from Mann-Kendall test for rainfall time series for annual totals and for bimesters indicated significant negative trends only for the fifth bimester for Sete Lagoas meteorological station ( $p$-value $=0.0497$ ). Significant positive trends were detected for the second bimester in the meteorological stations of Belo Horizonte $(p$-value $=0.0034)$ and Sete Lagoas ( $\mathrm{p}$-value $=0.0118)$. However, some remarks should be considered. The time series of rainfall began in the early 1960s and the series of flow rate began in the late 1930s. In addition, there are only three INMET old conventional stations in the basin. These aspects impose a certain level of uncertainty in the understanding of the effects of rainfall variability on the flow distributions in the studied area.

In their study on streamflow trend, Marengo and Alves (2005) concluded that the discharges of the Paraíba do Sul River, observed in stream gauging stations of the states São Paulo and Rio de Janeiro, has a negative trend for the last 50 years. The study pointed to a possible impact of anthropic influence (energy generation, irrigation and demand associated to population growth) as possible causes for these trends and not to a climate change of the rainfall distribution in the basin. Nevertheless, Santana et al. (2014) evaluated time series of rainfall and discharge in the Paraguay River Basin in the stations Barra do Bugres, Cáceres and Descalvado during the period of 1980-2005. According to the analyses, the discharge is basically a function of precipitation.

Rosin et al. (2015) studied five stream-gauging stations located in the interior of the Rio das Mortes Basin, in the State of Mato Grosso, Brazil. The authors verified a strong connection in relation to the type of use and withdraw of water resources for the station whose analyzes showed a negative trend in all series.

Uliana et al. (2015) studied trends in time series of rainfall and flow data for the city of Alegre, in the state of Espirito Santo, Brazil, and found that flow rate in October had increased 
by $34.2 \%$ since 1963 . They also detected a tendency of increase in rainfall for the months of August and September, since the years of 1967 and 1964, respectively, and concluded that this trend, among other possible factors, may have influenced the increase of the average flow rate for the month of October.

In a similar work, Vilanova (2014a) evaluated the existence of trends in time series of discharge and rainfall in the high Mogi-Guaçu region from 1973 to 2006. A negative trend was detected in both time series. The author suggests that the identified trends may be the result of climate change, initially affecting the region's rainfall and possibly generating a similar response at the discharges.

\section{CONCLUSIONS}

Among the probability distributions studied to describe discharge data of $\mathrm{Q}_{7}$, the best fits, in general, were verified for Gumbel and Rayleigh distributions, based on Anderson Darling and Criterion of Bayesian Information tests. However, the quality of fit by different distributions was differentiated for each stream gauging station.

Significant negative trends for the three stream gauging stations were detected for time series of $\mathrm{Q}_{7}$ and mean daily flow in the $4^{\text {th }}$ bimester. There were significant negative trends for the Santo Hipólito station also for the $5^{\text {th }}$ bimester. For the Várzea da Palma station, located near the mouth of the Das Velhas River, only for the first bimester significant negative trend in the flow series were not detected. Corresponding negative trends were not observed for the rainfall series from the studied meteorological stations.

\section{ACKNOWLEDGMENT}

The authors are grateful for the support of Fundação de Amparo à Pesquisa do Estado de Minas Gerais (FAPEMIG) and the financial support which was granted for the development of the project (CAG - APQ-03182-13).

\section{REFERENCES}

AGEVAP. Plano integrado de Recursos Hídricos - PIRH - da Bacia Hidrográfica do Rio Paraíba do Sul e planos de Ação de Recursos Hídricos - PARH - das Bacias Afluentes. Resende, 2016. 122p.

ALMEIDA, I. K.; SOBRINHO, T. A.; SANTOS, B. B.; STEFFEN, J. L.; BACCHI, C. G. V. Métodos estatísticos na determinação de vazão de referência. Comunicata Scientiae, v. 5, n. 1, p. 11-17, 2014.

BARUA, S.; MUTTIL, N.; NG, A. W. M.; PERERA, B. J. C. Rainfall trend and its implications for water resource management within the Yarra River catchment, Australia. Hydrological Processes, v. 27, n. 12, p. 1727-1738, 2013. https://dx.doi.org/10.1002/hyp.9311

BLAIN, G. C. Tendências e variações climáticas em séries anuais de precipitação pluvial do Estado de São Paulo. Bragantia, v. 69, n. 3, p. 765-770, 2010. https://dx.doi.org/10.1590/S0006-87052010000300031

CALOIERO, T.; COSCARELLI, R.; FERRARI, E.; MANCINI, M. Trend detection of annual and seasonal rainfall in Calabria (Southern Italy). International Journal of Climatology, v. 31, n. 1, p. 44-56, 2011. https://dx.doi.org/10.1002/joc.2055 
COMITÊ DA BACIA HIDROGRÁFICA DO RIO DAS VELHAS. Plano Diretor de Recursos Hídricos da Bacia Hidrográfica do Rio das Velhas 2015: Resumo Executivo. Belo Horizonte, 2015. 233 p.

COSTA, V. J.; FERREIRA, M.; CORDEIRO, M. T. A. Análise de séries temporais climáticas. Revista de Ciências Agroveterinárias, v. 14, n. 2, p. 169-177, 2015.

DALE, J.; ZOU, C. B.; ANDREWS, W. J.; LONG, J. M.; LIANG, Y.; QIAO, L. Climate, water use, and land surface transformation in an irrigation intensive watershed-Streamflow responses from 1950 through 2010. Agricultural Water Management, v. 160, p. 144152, 2015. https://dx.doi.org/10.1016/j.agwat.2015.07.007

DAMÁZIO, J. M.; COSTA, F. S. Stationarity of annual maximum daily streamflow time series in South-East brazilian rivers. Cadernos do IME. Série Estatística, v. 37, p. 29-30, 2014. https://dx.doi.org/10.12957/cadest.2014.18302

DETZEL, D. H. M.; MINE, M. R. M.; BESSA, M.; BLOOT, M. Cenários Sintéticos de Vazões para Grandes Sistemas Hídricos Através de Modelos Contemporâneos e Amostragem. RBRH - Revista Brasileira de Recursos Hídricos, v. 19, n. 1, p. 17-28, 2014. https://dx.doi.org/10.21168/rbrh.v19n1.p17-28.

EMILIANO, P. C.; VIVANCO, M. J. F.; MENEZES, F. S. M.; AVELAR, F. G. Fundamentos e comparação de critérios de informação: Akaike and Bayesian. Revista Brasileira Biomatemática, v. 27, n. 3, p. 394-411, 2009.

HIDROWEB. Séries históricas de estações. 2013. Available in: http://www.snirh.gov.br/hidroweb/publico/medicoes_historicas_abas.jsf. Access in: April 2018.

JOSEPH, J. F.; FALCON, H. E.; SHARIF, H. O. Hydrologic Trends and Correlations in South Texas River Basins: 1950-2009. Journal of Hydrologic Engineering, v. 18, n. 2, p. 1653-1662, 2013. https://dx.doi.org/10.1061/(ASCE)HE.1943-5584.0000709

KIBRIA, K. N.; AHIABLAME, L.; HAY, C.; DJIRA, G. Streamflow Trends and Responses to Climate Variability and Land Cover Change in South Dakota. Hydrology, v. 3 n. 1, 2016. https://doi.org/10.3390/hydrology3010002

LIMA, J. R. A.; NEVES, D. J. D.; ARAÚJO, L. E.; AZEVEDO, P. V. de. Identificação de tendências climáticas no Estado da Bahia. Revista de Geografia, v. 28, n. 3, p. 172-187, 2011.

LINDSEY, C.; SHEATHER, S. Model fit assessment via marginal model plots. The Stata Journal, v. 10, n. 2, p. 215-225, 2010. https://dx.doi.org/10.1177/1536867X1001000203

LOPES, T. R.; PRADO, G. Do; ZOLIN, C. A.; PAUlinO, J.; ANTONIEL, L. S. Regionalização de vazões máximas e mínimas para a bacia do rio Ivaí - PR. Irriga, v. 21, n. 1, p. 188-201, 2016. https://doi.org/10.15809/irriga.2016v21n1p188-201

MARENGO, J. A.; ALVES, L. M. Tendências Hidrológicas da Bacia do Rio Paraíba do Sul. Revista Brasileira de Meteorologia, v. 20, n. 2, p. 215-226, 2005.

MCLEOD, A. I. Kendall: Kendall rank correlation and Mann-Kendall trend test. 2011. Available in: https://CRAN.R-project.org/package=Kendall. Access in: April 2018.

MELLO, C. R.; VIOLA, M. R.; BESKOW, S. Vazões máximas e mínimas para bacias hidrográficas da região Alto Rio Grande, MG. Ciência e Agrotecnologia, v. 34, p. 494502, 2010. https://dx.doi.org/10.1590/S1413-70542010000200031 
MOOD, A. M.; GRAYBILL, F.; BOES, D. C. Introduction to the Theory of Statistics. 3th ed. New York: McGraw-Hill, 1974. 480 p.

PALISADE CORPORATION. Guide to Using @ Risk. Risk Analysis and Simulation AddIn for Microsoft ${ }^{\circledR}$ Excel - Versão.7.0.1. New York, 2016. 880 p.

PEREIRA, G. S.; CALDEIRA, F. C. Evaluation of the distribution of Gumbel in the determination of minimum flows of the Rio Negro sub-basin. Águas Subterrâneas, v. 32, n. 1, p. 11-16, 2018. https://dx.doi.org/10.14295/ras.v32i1.28926

PINTO, A. P.; LIMA, G. B.; ZANETTI, J. B. Análise comparativa de modelos de séries temporais para modelagem e previsão de regimes de vazões médias mensais do Rio Doce, Colatina - Espírito Santo. Ciência e Natura, v. 37, n. 4, p. 1-11, 2015. https://dx.doi.org/10.5902/2179460X17143

R CORE TEAM. R-3.3.1 for Windows (32/64 bit). 2016. Available in: https://cran.rproject.org/bin/windows/base/old/3.3.1/. Access in: April 2018.

RAZALI, N. M.; WAH, Y. B. Power comparisons of Shapiro-Wilk, Kolmogorov-Smirnov, Lilliefors and Anderson-Darling tests. Journal of Statistical Modeling and Analytics, v. 2, n. 1, p. 21-33, 2011.

ROSIN, C.; AMORIM, R. S. S.; MORAIS, T. S. T. Análise de tendências hidrológicas na bacia do rio das Mortes. Revista Brasileira de Recursos Hídricos, v. 20, n. 4, p. 99-998, 2015. https://dx.doi.org/10.21168/rbrh.v20n4.p 991-998

ROSSI, M. S.; THEBALDI, M. S. Vazões de referência do Rio São Miguel em Arcos (MG). Revista Agrogeoambiental, v. 9, n. 1, p. 77-86, 2017. https://dx.doi.org/10.18406/23161817v9n12017927

SALVADORI, N. Evaluation of non-stationarity in annual maximum flood series of moderately impaired watersheds in the upper Midwest and Northeastern United States. 2013. Dissertation (Master of Science in Environmental Engineering) Department of Civil and Environmental Engineering, Michigan Technological University, Michigan, 2013.

SALVIANO, M. F.; GROPPO, J. D.; PELlEGRINO, G. Q. Análise de tendências em dados de precipitação e temperatura no Brasil. Revista Brasileira de Meteorologia, v. 31, n. 1, p. $64-73,2016$. http://dx.doi.org/10.1590/0102-778620150003

SANTANA, M. F.; SOUZA, C. A.; OLIVEIRA JUNIOR, E. S. Análise de séries temporais de vazão e precipitação na bacia do rio Paraguai. Revista GeoPantanal, v. 8, n. 14, p. 6789, 2014.

SANTOS, L. C. C. Estimativa de Vazões Máximas de Projeto por Modelos Determinísticos e Probabilísticos. 2010. 80 p. Dissertação (Mestrado) - Universidade Federal do Espírito Santo, Espírito Santo, 2010.

SILVA, A. M.; OLIVEIRA, P. M.; MELLO, C. R.; PIERANGELI. C. Vazões mínimas e de referência para outorga na região do Alto Rio Grande, Minas Gerais. Revista Brasileira de Engenharia Agrícola e Ambiental, v. 10, n. 2, p. 374-380, 2006. https://dx.doi.org/10.1590/S1415-43662006000200019 
SILVA, B. M. B.; SILVA, D. D.; MOREIRA, M. C. Influência da sazonalidade das vazões nos critérios de outorga de uso da água: estudo de caso da bacia do rio Paraopeba. Revista Ambiente \& Água, v. 10, n. 3, p. 623-634, 2015. https://dx.doi.org/10.4136/ambiagua. 1587

SILVINO, A. N. O.; SILVEIRA, A.; MUSIS, C. R.; WYREPKOWSKI, C. C.; CONCEIÇÃO, F. T. Determinação de vazões extremas para diversos períodos de retorno para o Rio Paraguai utilizando métodos estatísticos. Geociências, v. 26, p. 369-378, 2007.

SMAKHTIN, V. U. Low flow hydrology: a review. Journal of Hydrology, v. 240, n. 3, p. 147 186, 2001. http://doi.org/10.1016/S0022-1694(00)00340-1

SOARES, D. B.; NÓBREGA, R. S.; GALVÍNCIO, J. D. Indicadores climáticos de desertificação na bacia hidrográfica do Rio Pajeú, Pernambuco. Revista Brasileira de Climatologia, v. 22, 2018. http://dx.doi.org/10.5380/abclima.v22i0.58557

SUHAILA, J.; DENI, S. M.; WAN ZIN, W. Z.; JEMAIN, A. A. Spatial patterns and trends of daily rainfall regime in Peninsular Malaysia during the southwest and northeast monsoons: 1975-2004. Meteorology and Atmospheric Physics, v. 110, n. 1, p.1-18, 2010. https://dx.doi.org/10.1007/s00703-010-0108-6

TAN, X. Z.; GAN, T. Y. Nonstationary analysis of annual maximum streamflow of Canada, Journal of Climate, v. 28, p. 1788-1805, 2015. https://doi.org/10.1175/JCLI-D-1400538.1

TAO, H.; GEMMER, M.; BAI, Y.; SU, B.; MAO, W. Trends of streamflow in the Tarim River Basin during the past 50 years: Human impact or climate change? Journal of Hydrology, v. 400, n. 1, p. 1-9, 2011. http://dx.doi.org/10.1016/j.jhydrol.2011.01.016

ULIANA, E. M.; SILVA, D. D. da; ULIANA, E. M.; RODRIGUES, B. S.; CORRÊDO, L. P. Análise de tendência em séries históricas de vazão precipitação: uso de teste estatístico não paramétrico. Revista Ambiente \& Água, v. 10, n. 1, 2015. https://dx.doi.org/10.4136/ambi-agua. 1427

VICTORINO, E. C.; MATIAS, G. C.; SILVA, T. B. S. DA; ALVES, R. C. P.; CARVALHO, L. G. de. Adequabilidade de diferentes distribuições de probabilidade aplicadas a uma série histórica de vazões mínimas para o rio Grande, na região de Barreiras (BA). In: CONGRESSO BRASILEIRO DE ENGENHARIA AGRÍCOLA, 42., 1-8 Jul., Campo Grande. Proceedings[...] Campo Grande: SBEA, 2014.

VILANOVA, M. R. N. Tendências Hidrológicas na região do Alto Rio Mogi-Guaçu, Sul de Minas Gerais. Revista Agrogeoambiental, v. 6, n. 3, p. 63-70, 2014a. https://dx.doi.org/10.18406/2316-1817v6n32014601

VILANOVA, M. R. N. Trends in Mean Annual Streamflows in Serra da Mantiqueira Environmental Protection Area. Brazilian Archives of Biology and Technology, v. 57, n. 6, p. 1004-1112, 2014b. https://dx.doi.org/10.1590/S1516-8913201402109 